\title{
Antibacterial and antifungal activities and phytochemical profile of leaf extract from different extractants of Ricinus communis against selected pathogens
}

\author{
Jennifer Suurbaar ${ }^{*}$, Richard Mosobil and Addai-Mensah Donkor
}

\begin{abstract}
Objectives: Ricinus communis leaves are used in herbal preparations for treating candidiasis, skin and wound infections in Ghana. This study aimed at comparing the phytochemical profile of aqueous, methanol, petroleum ether, ethyl acetate and ethanolic extracts of the leaves of Ricinus communis and determine the growth inhibitory activities, bactericidal, bacteriostatic and fungicidal effects of the respective extracts on Escherichia coli, Staphylococcus aureus, Pseudomonas aeruginosa, Klebsiella pneumonaie and Candida albicans.

Results: The aqueous, methanol and ethanol extracts were shown to contain most of the phytochemicals analyzed. All solvents extracts exhibited inhibitory activity against the growth of all microorganisms under study. The methanol extract showed highest zones of inhibition and was found to be statistically significant $(P<0.05)$ compared to other solvents extracts. All solvents extracts exhibited both bacteriostatic and bactericidal effects on the test organisms at varying concentration, with MIC values ranging from 3.13 to $25.0 \mathrm{mg} / \mathrm{ml}$ and MBCs were from 200 to $400 \mathrm{mg} / \mathrm{ml}$. MFCs of Candida albicans was between 200 and $400 \mathrm{mg} / \mathrm{l}$. Our data confirm the anti-bacterial and anti-fungal properties of $R$. communis and showed that the biologically relevant phytochemicals from the leaves of this plant can be extracted with the solvents aqueous, methanol and ethanol.
\end{abstract}

Keywords: Antibacterial, Antifungal, Ricinus communis, Escherichia coli, Staphylococcus aureus, Pseudomonas aeruginosa, Klebseilla pneumoniae, Candida albicans

\section{Introduction}

Plant kingdoms are the rich source of organic compounds, many of which have been used for medicinal purposes. There are many natural crude drugs from plants that have the potential to treat many disease and disorders and one of them is Ricinus communis [1, 2]. Ricinus communis is a species of flowering plant in the family, Euphorbiaceae. The parts of the plants used for medicinal purposes are the leaves, root, stem, fruits, complete aerial parts, the whole plant and flowers [3]. The plant is reported to contain antioxidant properties in

*Correspondence: suurbaar@gmail.com; dr.adonkor@uds.edu.gh; adaddaimensah@gmail.com

Department of Chemistry and Biochemistry, Faculty of Applied Sciences, University for Development Studies, Navrongo Campus, Tamale, Ghana its methanolic leaf extract $[4,5]$ anti-inflammatory activity [6], anti-diabetic activity [7] and antibacterial activity [4]. The plant has hepatoprotective effect [8] and has been used in the treatment of skin cancer [9].

A phytopharmacological review by Jena and Gupta in 2012, revealed that, Ricinus communis has proven to possess antimicrobial activities as they were used against dermatophytic and pathogenic bacterial strains $S$. aureus, $P$. aeruginosa as well as $K$. pneumoniae and E. coli [10]. Also, anti-fungal activity of the leaf was potent against Candida albicans [11]. The Ricinus communis possess wound healing activity due to the active constituent of castor oil which produce antioxidant activity and inhibit lipid peroxidation [12]. The leaves of $R$. communis are believed to be used in the form of a 
poultice or fomentation on sores, boils and swellings [3]. In this study, we validated the antimicrobial action of the extracts of the plant $R$. communis from Ghana using aqueous, methanol, petroleum ether, ethyl acetate and ethanolic solvents and also determined the bactericidal, fungicidal and bacteriostatic properties of the respective solvent extracts.

\section{Main text}

\section{Materials and methods}

\section{Plant material}

Plant material, Ricinus communis leaves were collected from different areas in Navrongo, Upper East Region, Ghana. The plant was identified and authenticated by a plant taxonomist at the herbarium of Ghana Herbaria, Northern Savanna Biodiversity; Savanna Herbarim. The voucher specimen was deposited with a number SH 720 in the herbarium.

\section{Preparation of plant crude extracts}

Plant material, Ricinus commmunis leaves were washed with distilled water and air dried at room temperature for 2 weeks. The leaves were ground into uniform powder.

The ethanol, methanol, petroleum ether, ethyl acetate and aqueous extracts were prepared by socking $100 \mathrm{~g}$ of the powdered plant materials in $1 \mathrm{l}$ of each extractant at room temperature for $48 \mathrm{~h}$. The extracts were filtered separately through whatman filter paper No 42 and concentrated using rotary evaporator (Heidoph 4001 efficient), warmed on water bath at $70{ }^{\circ} \mathrm{C}$ for the aqueous extract and temperature of $50{ }^{\circ} \mathrm{C}$ for ethanol, petroleum ether, ethyl acetate and methanol extracts, to obtain semi solid products.

\section{Phytochemical screening}

Phytochemical screening for the plant extracts were performed to determine the presence of tannins, saponins, terpenoids, polyuronoids, reducing sugars, flavonoids, alkaloids and anthraquinones using the method described elsewhere [12, 13].

\section{Preparation of extracts concentrations from various extractants}

The concentrations of the crude extracts obtained from the respective solvents were prepared using dimethylsulfuroxide (DMSO) to obtain concentrations of 200, $100,50,25,12.5,6.25,3.125$ and $1.5625 \mathrm{mg} / \mathrm{ml}$ for each extract.

\section{Test organism}

Disease-causing microorganism were taking into consideration and four bacteria and one fungus were considered. Selected bacterial species were E. coli, S. aureus, $P$. aeruginosa and $K$. pneumoniae and C. albican as the fungus. Clinical isolates of these microorganisms were obtained from the Microbiology Department of the Tamale Teaching Hospital in the Northern Region of Ghana, in the month of March 2016. Bacterial isolates were maintained at 2 and $8{ }^{\circ} \mathrm{C}$ on nutrient broth whilst the fungal isolates were maintained at $4{ }^{\circ} \mathrm{C}$ on potato dextrose agar.

\section{Agar well diffusion assay}

The modified agar well diffusion method described elsewhere [13] was employed.

\section{Test for antifungal activity}

In order to investigate the antifungal activity of the extracts, a micro dilution technique was used. The fungal spores were washed from the surface of agar plates with sterile $0.85 \%$ saline containing $0.1 \%$ Tween $80(\mathrm{v} / \mathrm{v})$. The spore suspension was adjusted with sterile saline to a concentration of approximately $1.0 \times 10^{7} \mathrm{cfu} / \mathrm{ml}$. The inocula were stored at $4{ }^{\circ} \mathrm{C}$ for further use. Dilutions of the inocula were cultured on solid potato dextrose agar to verify the absence of contamination and to check the validity of the inoculum.

\section{Inoculum preparation for minimum inhibitory concentration (MIC) and minimum bactericidal concentrations (MBC)}

Inocula were obtained from an overnight agar culture of the test organism. Inoculum for the MIC and MBC test was prepared by taking at least three to five well isolated colonies of the same morphology from agar plate culture. The top of each colony was touched with a sterile loop and the loop was transferred into a tube containing $5 \mathrm{ml}$ of normal saline and then vortexed. The broth culture was incubated at $37^{\circ} \mathrm{C}$ and monitored for approximately $4 \mathrm{~h}$ until it achieved the turbidity of $0.5 \mathrm{McF}$ arland standard $\left(1.5 \times 10^{8} \mathrm{cfu} / \mathrm{ml}\right)$.

\section{Determination of $M B C$ and $M I C$}

The tube diffusion method described elsewhere $[13,14]$ was employed for the determination of MBCs and MICs.

Determination of minimum fungicidal concentration (MFC) Applying the method of [14], the minimum fungicidal concentrations (MFCs) were determined by subculturing of $2 \mu \mathrm{l}$ from each of the wells showing no growth into microtiter plates containing $100 \mu \mathrm{l}$ of broth per well and further incubation for $72 \mathrm{~h}$ at $28{ }^{\circ} \mathrm{C}$. The lowest concentration with no visible growth was defined as MFC indicating 99.5\% killing of the original inoculum. Commercial standards, Flucanazole (Sigma), was used as positive control $(1-3000 \mu \mathrm{g} / \mathrm{ml})$ and negative 
control (DMSO-99.9\%) for fungus. All experiments were performed in duplicate and repeated three times for reproducibility.

\section{Statistical analysis}

Means and standard error of the mean were calculated for the zones of inhibition measured for the two sets of experiments in each case. These means were statistically compared using the one-way ANOVA to determine if they were significantly different at $P<0.05$.

\section{Results and discussion}

Pseudomonas aeruginosa, Klebsiella pneumoniae, Escherichia coli and many other $\beta$-lactamase producers have become a major clinical problem. Increased consideration has been focused on the usage of natural antimicrobial agents, especially from plant origins, due to their safety and efficacy as well as the fact that the majority of these plants are classified as generally recognized as safe. Indeed, natural products are used intensively as food preservatives, nutraceuticals as well as potential drugs for the treatment and prevention of various diseases and conditions including: cancer, cardiovascular disorders, aging and many others. Recently, for these reasons, global education have been conducted for the characterization, utilization and extraction of biological and pharmacological active compounds from plant origins.

In this study, the leaves of Ricinus communis were used, this is because, the leaves of the plant are mostly used in the treatment of wound infections, candidiasis and other skin diseases locally. For $100 \mathrm{~g}$ each in the different solvent the percentage yields were determined and were found to be $5.2,6.0,6.8,7.2$ and $8.3 \%$ for ethanol, aqueous, petroleum ether, ethyl acetate and methanol respectively. The phytochemical analysis of the different leaf extracts from the various extractants, aqueous, methanol and ethanol showed the presence of tanins, saponnins, terpenoids and flavonoids. Petroleum ether and ethyl acetate were devoid of tanins and flavonoids, probably resulting in low inhibitory activity against the pathogens. Most of these phytochemicals are the basis for plants medicinal properties and these are starting materials for production of new drugs today.

The extracts were found to be effective against the pathogens used in this study, which highlight the potential of herbal drugs and their possible use as local medicine. Utilising a concentration of $50 \mathrm{mg} / \mathrm{ml}$ of the crude extracts from the various extractants, methanol extract showed appreciably equal but higher inhibitory activity against all the bacteria used in this research compared to the other solvent extracts. The observed zones of inhibition for the methanol extract were $20 \pm 2.82,20 \pm 0.71$, $21 \pm 2.12$ and $24 \pm 1.41(\mathrm{~mm})$ for $E$. coli, S. aureus, $P$. aeruginosa and $K$. pneumoniae respectively (Additional file 1). The ethyl acetate extract exhibited relatively lower inhibitory activity against the bacterial strains, with zones of $11.5 \pm 0.71,12.0 \pm 1.41,14.5 \pm 2.12$ and $14.5 \pm 0.71$ (mm) for E. coli, S. aureus, P. aeruginosa and K. pneumoniae respectively.

As the concentration of the crude extracts were raised to $100 \mathrm{mg} / \mathrm{ml}$ the methanol extract inhibitory activity against $E$. coli and $S$. aureus were approximately the same as that of the $50 \mathrm{mg} / \mathrm{ml}$ but inhibitory activity increased appreciably against $P$. aeruginosa and $K$. pneumoniae. The ethanol extract showed a significant higher inhibitory activity against $P$. aeruginosa with a zone of $24 \pm 1.8 \mathrm{~mm}$ (Additional file 2). Similar trend was observed by raising the extract concentrations to $200 \mathrm{mg} / \mathrm{ml}$. The antimicrobial activities of methanol, aqueous and ethanol extracts were comparable with that of amoxicillin, the standard antibiotic (Additional file 3) whilst the negative control (DMSO-99.99\%) showed no inhibitory activity.

Phytochemicals such as, tannins, saponins, terpenoids, polyuronoids, reducing sugars, flavonoids, alkaloids and anthraquinones were all detected in methanol extract (Table 1). The high antibacterial activity in the methanolic extract may be due to the presence of high amount of tannins, flavonoids, and terpenoids. Tannins and flavonoids possesses similar mechanism by providing a source of stable free radical and also forms complex with nucleophilic amino acids in protein leading to the inactivation of the protein and loss of function, their

Table 1 Phytochemical profile of plant extracts

\begin{tabular}{|c|c|c|c|c|c|c|c|c|}
\hline Solvents & Tannins & Saponins & Polyuronoids & Reducing sugars & Terpenoids & Flavonoids & Alkaloids & Anthraquinones \\
\hline Aqueous & + & + & + & + & + & + & - & - \\
\hline Ethanol & + & + & + & - & + & + & - & + \\
\hline methanol & + & + & + & + & + & + & + & + \\
\hline Petroleum ether & - & - & - & - & + & - & + & - \\
\hline Ethyl acetate & - & + & - & - & + & - & + & + \\
\hline
\end{tabular}

+, presence; -, not detected 
potential antimicrobial effect is great as they probably target microbial cell of surface-exposed adhesins, cell wall polypeptides and membrane bound enzymes [15]. Terpenoids are for dissolution of the cell wall of microorganisms by weakening the membranous tissue [16]. Saponins have the ability to cause leakage of proteins and certain enzymes from the cell [17].

Both petroleum ether and ethyl acetate extracts were devoid of the phytochemicals mentioned above, justifying their lower inhibitory activity against the tested strains employed in the current research.

The minimum inhibitory concentration (MIC) and minimum bactericidal concentration (MBC) of Ricinus communis leaf extract on the isolated pathogens ranged from 3.13 to $25.0 \mathrm{mg} / \mathrm{ml}$ and MBCs were from 200 to $400 \mathrm{mg} / \mathrm{ml}$ (Table 2). The MICs depending on the microbe and the extract, greater sensitivity was observed in methanol, ethanol and aqueous extracts and the least sensitive was petroleum ether and ethyl acetate extracts where most of their MBCs were undetected. Jayaseelan and Jashothan reported in their study that methanol and ethanol extracts revealed lowest MIC value $(5 \mathrm{mg} / \mathrm{ml})$ against $S$. aureus and E. coli [18]. Another research group reported that methanol extract of Ricinus communis was found to be more active against $S$. aureus, $P$. aeruginosa and $K$. pneumoniae [19]. In this study the more susceptible test organisms to the methanol extract were $P$. aeruginosa and K. pneumoniae. A similar study conducted by Kensa and Yasmin showed that the more susceptible organism was E. coli [20], however, Chwukuka et al. showed that Ricinus communis leaf extract did not inhibit E. coli [21]. The differences observed may be due to the different extraction process and the difference in the susceptibilities of the clinical strains used.

Interestingly, the fungus, C. albican employed in this research was susceptible to all the extracts used, of which the methanol extract presented the highest inhibitory activity, followed by ethanol extract. Compared with the positive control (Fluconazole), the extracts exhibited significantly high inhibitory activity against the fungus with MFCs ranging from 200 to $400 \mathrm{mg} / \mathrm{ml}$ (Fig. 1) whilst the negative control (DMSO-99.99\%) exhibited no inhibitory activity against the fungus. The results of this current research are in agreement with other findings supporting that most compounds in medicinal plants are more extracted in methanol [22].

\section{Conclusion}

The extractants used have a major impact on inhibitory activity of the bioactive agents. In this study, methanol extract showed maximum antimicrobial activity, followed by ethanol and aqueous extracts. Petroleum ether and ethyl acetate showed the least antibacterial activity, suggestive of the active compounds having antimicrobial potential be extracted using appropriate solvent. This research gives a scientific validation to the fact that bioactive components in the plant Ricinus communis are extracted substantially in methanol and exhibited highly promising antibacterial and antifungal inhibitory activity.

Table 2 MIC and MBC and MFC ( $\mathrm{mg} / \mathrm{ml})$ of $R$. communis extracts on the bacterial and fungal clinical isolates

\begin{tabular}{|c|c|c|c|c|c|c|c|c|c|c|}
\hline \multirow[t]{3}{*}{ Test organisms } & \multicolumn{10}{|c|}{ Different solvents } \\
\hline & \multicolumn{2}{|c|}{ Aqueous } & \multicolumn{2}{|c|}{ Ethanol } & \multicolumn{2}{|c|}{ Methanol } & \multicolumn{2}{|c|}{ PET ether } & \multicolumn{2}{|c|}{ Ethyl ace } \\
\hline & MIC & MBC & MIC & MBC & MIC & MBC & MIC & MBC & MIC & MBC \\
\hline E. coli & 6.25 & UD & 6.25 & UD & 12.5 & 400 & 12.5 & UD & 25 & 400 \\
\hline S. aureus & 3.13 & 300 & 25.0 & 400 & 6.25 & 300 & 12.5 & 300 & 12.5 & 200 \\
\hline P. aeruginosa & 3.13 & 200 & 6.25 & 200 & 3.13 & 300 & 25 & UD & 25 & UD \\
\hline K.pneumoniae & 12.50 & 400 & 6.25 & 200 & 6.25 & 400 & 25 & UD & 25 & UD \\
\hline Fungus & & MFC & & MFC & & MFC & & MFC & & MFC \\
\hline C. albicans & 12.5 & 300 & 25 & 300 & 12.5 & 200 & 25 & 300 & 25 & 400 \\
\hline
\end{tabular}

UD, undetected; PET, petroleum ether; Ethyl ace, ethyl acetate 


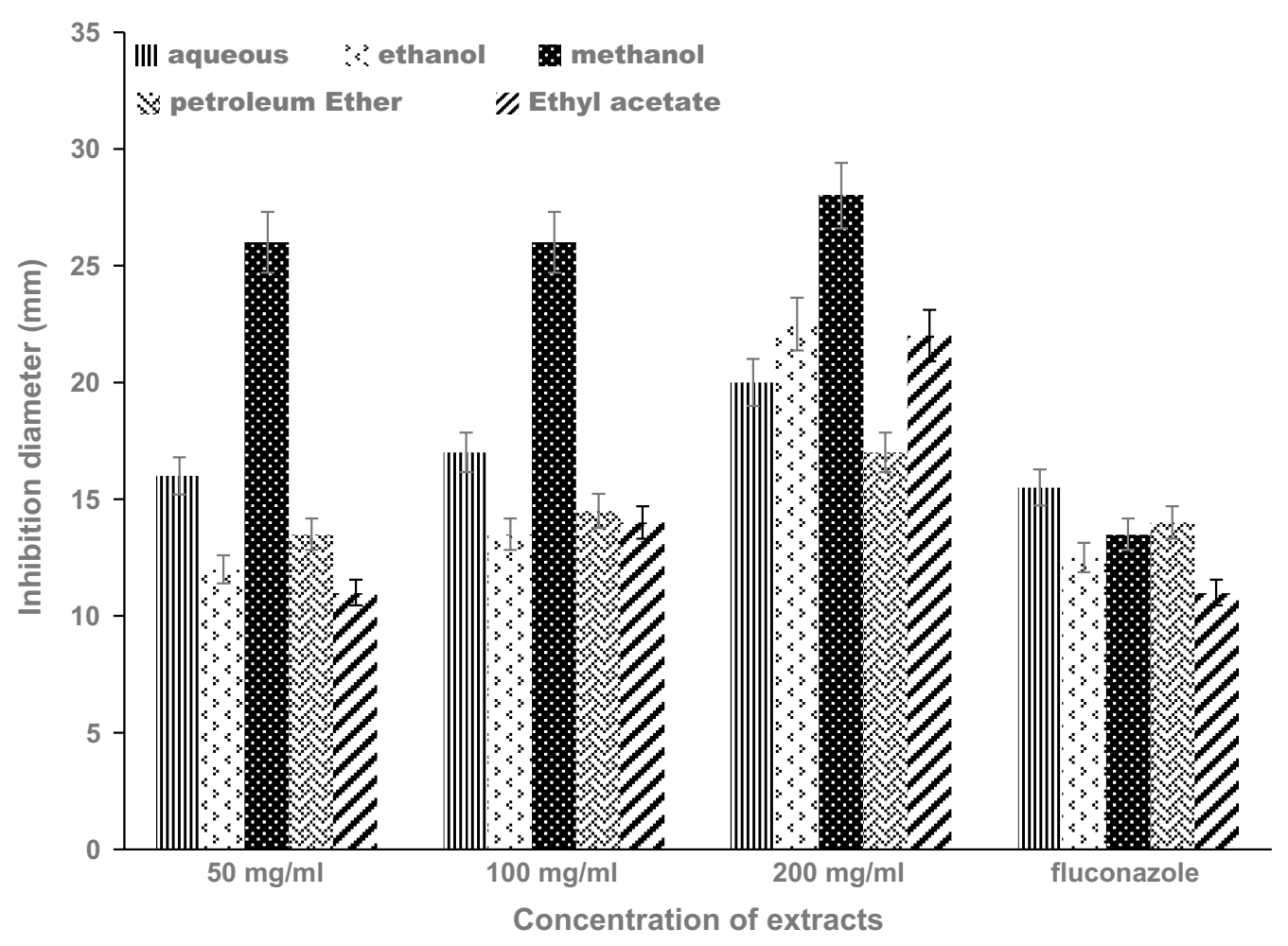

Fig. 1 Representative antifungal activity of 50, 100 and $200 \mathrm{mg} / \mathrm{ml}$ of ethanol, methanol, aqueous, petroleum ether and ethyl acetate crude extracts of Ricinus communis against C. albcans. The data shown represent the average of three wells treated on the same day. The experiment was repeated twice and day-to-day variation was found to be within onefold of the presented data

\section{Limitation}

Acquisition of reagents and chemicals was difficult and that caused hindrance in conducting other test of interest.

\section{Additional files}

Additional file 1. Representative antibacterial activity of $50 \mathrm{mg} / \mathrm{ml}$ ethanol, methanol, aqueous, petroleum ether and ethyl acetate crude extracts of Ricinus communis against E. coli, S. aureus, P. aeruginosa and $K$. pneumoniae. The data shown represent the average of three wells treated on the same day. The experiment was repeated twice and day-to-day variation was found to be within onefold of the presented data.

Additional file 2. Representative antibacterial activity of $100 \mathrm{mg} / \mathrm{m}$ ethanol, methanol, aqueous, petroleum ether and ethyl acetate crude extracts of Ricinus communis against $E$. coli, S. aureus, P. aeruginosa and $K$ pneumoniae. The data shown represent the average of three wells treated on the same day. The experiment was repeated twice and day-to-day variation was found to be within onefold of the presented data.

Additional file 3. Representative antibacterial activity of $200 \mathrm{mg} / \mathrm{ml}$ ethanol, methanol, aqueous, petroleum ether and ethyl acetate crude extracts of Ricinus communis against $E$. coli, S. aureus, $P$. aeruginosa and $K$ pneumoniae. The data shown represent the average of three wells treated on the same day. The experiment was repeated twice and day-to-day variation was found to be within onefold of the presented data.

\section{Abbreviations}

R. communis: Ricinus communis; K. pneumoniae: Klebsiella pneumoniae; E. coli: Escherichia coli; P. aeruginosa: Pseudomonas aeruginosa; S. aureus: Staphylococcus aureus; C. albicans: Candida albicans; MIC: minimum inhibitory concentration; MBC: minimum bactericidal concentration; MFC: minimum fungicidal concentration; STD: standard deviation.

\section{Authors' contributions}

JS, AMD, RM conceived and designed the study; RM collected the plant samples and performed the experiments; JS performed statistical/data analysis; AMD, JS, RM wrote the paper. All authors read and approved the final manuscript.

\section{Acknowledgements}

The authors would like to acknowledge the support of the technical staff of the microbiology Department, Navrongo Health Research Centre (NHRC). We would also like to thank the staff of Office of Research Support, NHRC for administrative assistance.

\section{Competing interests}

The authors declare that they have no competing interests.

\section{Availability of data and materials}

The datasets used and analyzed during the current study are available from the corresponding author on a reasonable request.

\section{Consent for publication}

Not applicable. 


\section{Ethics approval and consent to participate}

This research did not involve data collected from humans or animals and therefore, there was no permission required to collect and study the plant material, Ricinus communis in Ghana.

\section{Funding}

This study was supported by the Faculty of Applied Sciences, University for Development Studies. Funders had no role in study design, data collection and analysis, decision to publish, or preparation of the manuscript.

\section{Publisher's Note}

Springer Nature remains neutral with regard to jurisdictional claims in published maps and institutional affiliations.

Received: 5 June 2017 Accepted: 25 November 2017

Published online: 01 December 2017

\section{References}

1. Chanda S, Baravalia Y. Novel leads from herbal drugs for infectious skin diseases. Curr Res Technol Educ Topics Appl Microbiol Microbial Biotechnol. 2010;1:451-6.

2. Begum D, Nath SC. Ethnobotanical review of medicinal plants used for skin diseases and related problems in Northeastern India. J Herbs Spices Med Plants. 2000:7(3):55-93.

3. Rana M, Dhamija H, Prashar B, Sharma S. Ricinus communis L.- a review. Int J PharmTech Res. 2012;4(4):1706-11.

4. Rao N, Mittal S, Menghani E. Assessment of phytochemical screening, antioxidant and antibacterial potential of the methanolic extract of Ricinus communis I. Asian J Pharm Technol. 2013;3(1):20-5.

5. Gupta MK, Sharma P, Singh R, Ansari S. Antioxidant activity of the methanolic extract of Ricinus communis leaves. Asian J Chem. 2007;19(5):3387.

6. Saini AK, Goyal R, Gauttam VK, Kalia AN. Evaluation of anti-inflammatory potential of Ricinus communis Linn leaves extracts and its flavonoids content in Wistar rats. J Chem Pharm Res. 2010;2(5):690-5.

7. Shokeen P, Anand P, Murali YK, Tandon V. Antidiabetic activity of 50\% ethanolic extract of Ricinus communis and its purified fractions. Food Chem Toxicol. 2008;46(11):3458-66.
8. Shukla B, Visen P, Patnaik G, Kapoor N, Dhawan B. Hepatoprotective effect of an active constituent isolated from the leaves of Ricinus communis Linn. Drug Dev Res. 1992;26(2):183-93.

9. Prakash E, Gupta D. In vitro study of extracts of Ricinus communis Linn on human cancer cell lines. J Med Sci Public Health. 2014;2(1):15-20.

10. Jena J, Gupta AK. Ricinus communis Linn: a phytopharmacological review. Int J Pharm Pharm Sci. 2012:4(4):25-9.

11. Khan JA, Yadav KP. Assessment of antifungal properties of Ricinus communis. J Pharm Biomed Sci. 2011;11(11)

12. Ciulei I. Methodology for analysis of vegetable drugs. Practical manual on industrial utilization of medicinal and aromatic plants Bucharest, Ministry of Chemical Industrie. 1982

13. Donkor AM, Mosobil R, Suurbaar J. In vitro bacteriostatic and bactericidal activities of Senna alata, Ricinus communis and Lannea barteri extracts against wound and skin disease causing bacteria. J Anal Pharm Res. 2016;3(1)46. https://doi.org/10.15406/japlr.2016.03.00046

14. Lin J, Opoku A, Geheeb-Keller M, Hutchings A, Terblanche S, Jäger AK, Van Staden J. Preliminary screening of some traditional Zulu medicinal plants for anti-inflammatory and anti-microbial activities. J Ethnopharmacol. 1999;68(1):267-74.

15. Stern JL, Hagerman AE, Steinberg PD, Mason PK. Phlorotannin-protein interactions. J Chem Ecol. 1996;22(10):1877-99.

16. Hernández NE, Tereschuk ML, Abdala LR. Antimicrobial activity of flavonoids in medicinal plants from Tafı 0301; del Valle (Tucumán, Argentina). J Ethnopharmacol. 2000;73(1):317-22.

17. Zablotowicz RM, Hoagland RE, Wagner SC. Effect of saponins on the growth and activity of rhizosphere bacteria. Saponins Used in Food and Agriculture: Springer; 1996. p. 83-95

18. Jeyaseelan EC, Jashothan PJ. In vitro control of Staphylococcus aureus (NCTC 6571) and Escherichia coli (ATCC 25922) by Ricinus communis L. Asian Pacific J Trop Biomed. 2012;2(9):717-21.

19. Naz R, Bano A. Antimicrobial potential of Ricinus communis leaf extracts in different solvents against pathogenic bacterial and fungal strains. Asian Pacific J Trop Biomed. 2012;2(12):944-7.

20. Kensa V, Yasmin S. Phytochemical screening and antibacterial activity on Ricinus communis L.. Plant Sci Feed. 2011;1(9):167-73.

21. Chukwuka K, Ikheloa J, Okonko I, Moody J, Mankinde T. The antimicrobial activities of some medicinal plants on Escherichia coli as an agent of diarrhea in livestock. Adv Appl Sci Res. 2011;2(4):37-48.

22. Chandrasekaran M, Venkatesalu V. Antibacterial and antifungal activity of Syzygium jambolanum seeds. J Ethnopharmacol. 2004;91(1):105-8.

\section{Submit your next manuscript to BioMed Central and we will help you at every step:}

- We accept pre-submission inquiries

- Our selector tool helps you to find the most relevant journal

- We provide round the clock customer support

- Convenient online submission

- Thorough peer review

- Inclusion in PubMed and all major indexing services

- Maximum visibility for your research

Submit your manuscript at www.biomedcentral.com/submit
Ciomed Central 